mgr inż. Łukasz Dul ${ }^{1}$

Przyjęty/Accepted/Принята: 26.06.2014;

Zrecenzowany/Reviewed/Рецензирована: 17.05.2015;

Opublikowany/Published/Опубликована: 30.09.2015;

\title{
Przegląd technologii wytwarzania hełmów strażackich oraz możliwości podniesienia poziomu bezpieczeństwa przez nie gwarantowanego
}

\author{
A Review of Manufacturing Technologies and Potential for Improving \\ the Safety Level Guaranteed by Firefighting Helmets
}

\section{Обзор технологии производства пожарных шлемов и возможности повышения уровня гарантируемой ими безопасности}

\begin{abstract}
ABSTRAKT
Cel: Celem artykułu jest przegląd technologii wytwarzania hełmów strażackich oraz analiza możliwości podniesienia poziomu bezpieczeństwa przez nie gwarantowanego. W artykule przedstawiono aspekty wykorzystania tkanin z pianki węglowej w wytwarzaniu skorup hełmów wykorzystywanych w ochronie przeciwpożarowej. W zasadniczej części artykułu przedstawiona została analiza możliwości podniesienia poziomu bezpieczeństwa gwarantowanego przez hełmy strażackie. Analiza ta oparta jest na wytycznych zawierających minimalne wymagania odnośnie ochrony przeciwpożarowej określone przez amerykańskie stowarzyszenie National Fire Protection Association (NFPA). Wprowadzenie: Gruntowna analiza dostępnej literatury krajowej, jak również międzynarodowej doprowadziła do wysnucia wniosku, że występuje niewielka ilość źródeł bezpośrednio dotyczących przedmiotu oraz tematyki przedstawionego artykułu. Tak więc niniejsze opracowanie może stanowić znaczące źródło informacji dla badaczy, naukowców oraz instytucji badawczych zainteresowanych tematyką technologii wytwarzania odzieży ochronnej, w tym przede wszystkim hełmów strażackich jak również możliwościami podniesienia poziomu bezpieczeństwa przez nie gwarantowanego wykorzystywanymi w Stanach Zjednoczonych.

Metodologia: Na potrzeby opracowania danego artykułu dokonano gruntownego przeglądu dostępnej literatury o tematyce związanej bezpośrednio lub pośrednio z zagadnieniami technologii wytwarzania odzieży ochronnej, jak również możliwościami podniesienia poziomu bezpieczeństwa przez nią gwarantowanego. W wyniku przeglądu literatury dokonano selekcji najbardziej wartościowych oraz adekwatnych źródeł tematycznych. W następnej kolejności dokonano analizy treści wyselekcjonowanych wcześniej źródeł. Analiza pozwoliła na postawienie kluczowych pytań, napisanie artykułu oraz wyciągnięcie wniosku w zakresie przedstawianej tematyki.

Wnioski: W artykule dokonano przeglądu technologii wytwarzania hełmów strażackich o określonych własnościach, jak również tematyki związanej z możliwościami podniesienia poziomu bezpieczeństwa gwarantowanego przez hełmy strażackie wykorzystywane w Stanach Zjednoczonych. Stwierdzono, że pianki węglowe używane do wytwarzania hełmów strażackich mogą być w stanie zapewnić wymaganą ochronę dla głowy użytkownika zarówno przed oddziaływaniami mechanicznymi, jak i termicznymi. Z kolei wnioski w odniesieniu do możliwości podniesienia poziomu bezpieczeństwa gwarantowanego przez tkaniny ochronne mówią o istnieniu znacznego potencjału badawczego w badaniu wpływu długości fal promieniowania cieplnego na wytrzymałość termiczną hełmów strażackich. Przytoczone wnioski są zgodne z normalizacją obowiązującą w Stanach Zjednoczonych, a artykuł stwarza możliwość porównania ich z normami europejskimi (PN-EN 443).
\end{abstract}

Słowa kluczowe: ochrona przeciwpożarowa, wytwarzanie, podniesienie poziomu bezpieczeństwa, hełm Typ artykułu: artykuł przeglądowy

\section{A BSTRACT}

Aim: The purpose if this article is to review manufacturing technologies and simultaneously examine the potential for improving the safety level of firefighting helmets. This paper presents issues associated with the use of carbon foam in the manufacture of shells for protection helmets worn by firefighters. The main part of the article presents an analysis of potential for increasing the level of safety guaranteed by firefighter helmets. The analysis is based on guidelines, which cover minimum requirements for fire protection, defined by the United States, National Fire Protection Association (NFPA).

Introduction: A fundamental review of accessible national and international literature revealed that there is only a small number of sources, which deal directly with the topic exposed in this article. Therefore, details from this study may provide a significant source of information

\footnotetext{
Politechnika Warszawska / Warsaw University of Technology, Poland; lukasz.dul@itc.pw.edu.pl;
} 
for researchers as well as research institutions interested in the subject of manufacturing technology of protective clothing, including primarily firefighting helmets, with the view of enhancing the guaranteed safety level guaranteed through their use in the Unites States. Methodology: For the purposes of this study, which bears the attributes of a review article, a fundamental review was carried out of accessible literature dealing directly or indirectly with issues concerning manufacturing technology of protective clothing as well as examine the potential for raising safety levels guaranteed by the use of such clothing. From the literature review, most valuable and appropriate thematic sources were selected and exposed to a content analysis. The analysis allowed for the formulation of key questions, construction of the article and extraction of relevant conclusions

Conclusions: The article reviewed technologies used in the manufacture of helmets, utilized by firefighters, which contain specific properties and addressed issues concerned with the potential for increasing the safety level guaranteed by firefighting helmets used in the United States. It was found that carbon foam used in the manufacture of helmets may provide the required level of protection to the user against thermal and mechanical influences. In turn, conclusions concerning the likelihood of increasing safety levels, guaranteed by the protective fabric, reveal the existence of significant research potential in the study of impact created by wavelengths of thermal radiation on the thermal resistance of firefighting helmets. Listed conclusions are consistent with norms applicable in the United States and this article facilitates a comparison between United States norms and European ones (PN-EN 443).

Keywords: protection from fires, manufacture, increasing the safety level, helmet

Type of article: review article

\section{АННОТАЦИЯ}

Цель: Целью данной статьи является обзор технологии производства пожарных шлемов, а также анализ возможности повышения уровня безопасности, которую они гарантируют. В статье были представлены аспекты использования тканей из углеродной пены в производстве корпусов пожарных шлемов. В основной части статьи был представлен анализ возможностей повышения уровня безопасности, которую обеспечивают пожарные шлемы. Анализ основан на положениях, содержащихся в американской ассоциации National Fire Protection Association и предусматривающих минимальные требования относительно пожарной охраны.

Введение: Исчерпывающий анализ имеющейся национальной и международной литературы привел к выводу, что насчитывается очень мало источников, касающихся предмета и темы данной статьи. Поэтому данная работа может являться важным источником информации для исследователей, учёных и исследовательских институтов, заинтересованных темой технологии производства защитных средств, в том числе, прежде всего, пожарных шлемов, используемых в США, а также для повышения уровня безопасности, которую они гарантируют.

Методология: Для создания данной обзорной работы был проведен исчерпывающий анализ имеющейся литературы, касающейся непосредственно или косвенно технологии производства защитной одежды (элементов индивидуальной защиты), как и возможности повышения уровня гарантируемой ею безопасности. В результате обзора литературы были выбраны наиболее ценные и необходимые тематические источники. Далее был сделан анализ содержания выбранных ранее источников. Анализ позволил поставить ключевые вопросы, написать статью и сделать вывод относительно представляемой тематики. Выводы: В статье сделан обзор технологии производства пожарных шлемов определённых характеристик, а также темы, связанной с возможностями повышения уровня безопасности, гарантируемой пожарными шлемами в США. Было установлено, что углеродная пена, используемая для продукции шлемов, в состоянии обеспечить требуемую защиту головы пользователя как от механических, так и термических воздействий. Кроме того, выводы относительно возможности повышения уровня безопасности гарантирумемой защитными материалами показывают, что значительным исследовательским потенциалом обладают исследования влияния длины волн теплового излучения на термическую устойчивость пожарных шлемов. Выводы, представленные в статье, соответствуют стандартам, действующим в США, а статья предоставляет возможность сравнить их с европейскими стандартами (PN-EN 443).

Ключевые слова: пожарная охрана, производство, повышение уровня безопасности, шлем

Вид статьи: обзорная статья

\section{Wprowadzenie}

W niniejszym artykule dokonano analizy technologii wytwarzania hełmów strażackich. Należy zauważyć, iż w dostępnej literaturze występuje niewiele pozycji dotyczących bezpośrednio tematyki będącej przedmiotem analizy, stąd też opracowanie może stanowić znaczące źródło informacji. W artykule zamieszczono najważniejsze oraz najbardziej kongruentne informacje i spostrzeżenia. W pierwszej części artykułu przedstawione zostały strategie walki z obciążeniami cieplnymi podczas oraz po działaniach ratowniczo-gaśniczych, jak również uwarunkowania regulacji temperatury podczas pracy w środowisku wysokiej temperatury. Z kolei główną część artykułu stanowi przegląd technologii wytwarzania oraz analiza możliwości podniesienia poziomu bezpieczeństwa gwarantowanego przez hełmy strażackie w Stanach Zjednoczonych. Przytoczone $w$ artykule eksperymenty oraz rozwiązania dotyczące konstrukcji hełmów strażackich umożliwiają porównanie rożnic wynikających z wymagań obowiązujących w Stanach Zjednoczonych oraz w Unii Europejskiej.

\section{Strategie walki z obciążeniami cieplnymi podczas oraz po akcjach ratowniczo- -gaśniczych [1-2]}

Temperatura ludzkiego ciała jest postrzegana za prawidłową, jeżeli jej wysokość oscyluje w granicach $37^{\circ} \mathrm{C}$. Upośledzenie funkcji organizmu może pojawić się, kiedy temperatura ciała utrzymuje się powyżej $38^{\circ} \mathrm{C}$. 
Odzież ochronna hamuje przenoszenie ciepła pomiędzy ciałem użytkownika a zewnętrznym środowiskiem. W momencie, gdy zewnętrzne obciążenie cieplne jest większe aniżeli obciążenie cieplne ciała, odzież ochronna chroni organizm. Odzież ochronna wpływa na odprowadzanie ciepła na dwa sposoby. Po pierwsze izolacja zmniejsza wymianę ciepła na drodze konwekcji, przewodzenia oraz promieniowania. Ponadto jeżeli odzież nie jest przepuszczalna dla pary wodnej, chłodzenie ciała poprzez odparowanie potu nie występuje. Proces wytwarzania odzieży ochronnej powinien uwzględniać konieczność osiągnięcia równowagi pomiędzy tymi elementami. Z kolei ograniczona wentylacja może być realizowana za pośrednictwem efektu kominowego, kiedy ciepłe, wilgotne powietrze opuszcza odzież poprzez talię oraz szyję i jest zastępowane chłodniejszym powietrzem $z$ dołu. Należy jednak zauważyć, iż pasy aparatu oddechowego zmniejszają ten efekt. Odzież ochronna o jasnym kolorze zapewnia niewielką poprawę w czasie rzeczywistych warunków akcji ochrony przeciwpożarowych. Korzystnym elementem może być tak zwana oddychająca paroizolacja, która może powodować poprawę chłodzenia ciała. Jej efekty jednak zmniejszają się podczas rzeczywistych warunków przeciwpożarowych. Aby utrzymać efektywność, odzież (płaszcze ochronne) powinna być utrzymywana w czystości.

\section{Uwarunkowania regulacji temperatury podczas pracy $\mathrm{w}$ środowisku wysokiej temperatury [3]}

Kolejna analiza badawcza przeprowadzona przez Nigela A.S. Taylora dotyczy zagadnień związanych z uwarunkowaniami regulacji temperatury podczas pracy użytkowników w środowiskach charakteryzujących się wysokimi temperaturami. Analiza wykazała, że ludzie są w stanie pracować w różnego rodzaju środowiskach termicznych, jednak optymalne funkcje fizjologiczne uzależnione są od homeostazy termicznej, która $\mathrm{z}$ kolei uzależniona jest od metabolicznej produkcji ciepła oraz zdolności środowiska pracy do wpływania na chłodzenie ciała poprzez parowanie. Adaptacja do warunków cieplnych oraz zabiegi chłodzenia ciała przed wykonaniem pracy mogą wpływać na rozszerzenie dopuszczalnego zakresu temperatury, w jakiej użytkownik może wykonywać bezpiecznie swoją pracę. Zabiegi adaptacyjne nie muszą być korzystne dla użytkowników ubranych w hermetyzowaną odzież, gdzie wzrost potliwości ma znacznie większe znaczenie w ocenie komfortu termicznego. Dla tego typu odzieży zalecane są procesy chłodzenia przed pracą oraz chłodzenie pomocnicze.

\section{Aspekty wykorzystania tkanin z pianki węglowej w skorupach hełmów strażackich [4]}

Hełmy strażackie wykorzystywane są do ochrony przed naprężeniami mechanicznymi wynikającymi przede wszystkim z oddziaływania elementów znajdujących się na miejscu akcji ratowniczo-gaśniczej (takich jak gruz, różnego rodzaju śmieci oraz zanieczyszczenia). Drugim elementem jest ochrona przed naprężeniami termicznymi będącymi wynikiem pożaru. W związku z tym hełm powinien spełniać wymagania dwóch testów: testu odporności na oddziaływanie płomienia oraz na oddziaływanie wpływu mechanicznego. Zazwyczaj konstrukcja hełmu składa się z dwóch zasadniczych warstw: skorupy hełmu oraz wkładki ochronnej przeciw oddziaływaniom mechanicznym. Zazwyczaj skorupa hełmu charakteryzuje się opornością na oddziaływania mechaniczne, termiczne, niewielką masą oraz trwałością.

Pianki węglowe są materiałami o strukturze komórkowej, które mogą posiadać relatywnie szerokie zastosowanie ze względu na ich niezwykle mały ciężar, optymalne właściwości mechaniczne i termiczne oraz możliwości wykorzystywania ich jako izolatorów termicznych. Ponadto ze względu na ich porowatość bardzo dobrze sprawdzają się jako amortyzatory. Pianki mogą być również wykorzystywane w zastosowaniach biologicznych.

Na rycinie 1 przedstawiono porównanie właściwości materiału opartego na piance węglowej z innego rodzaju materiałami.

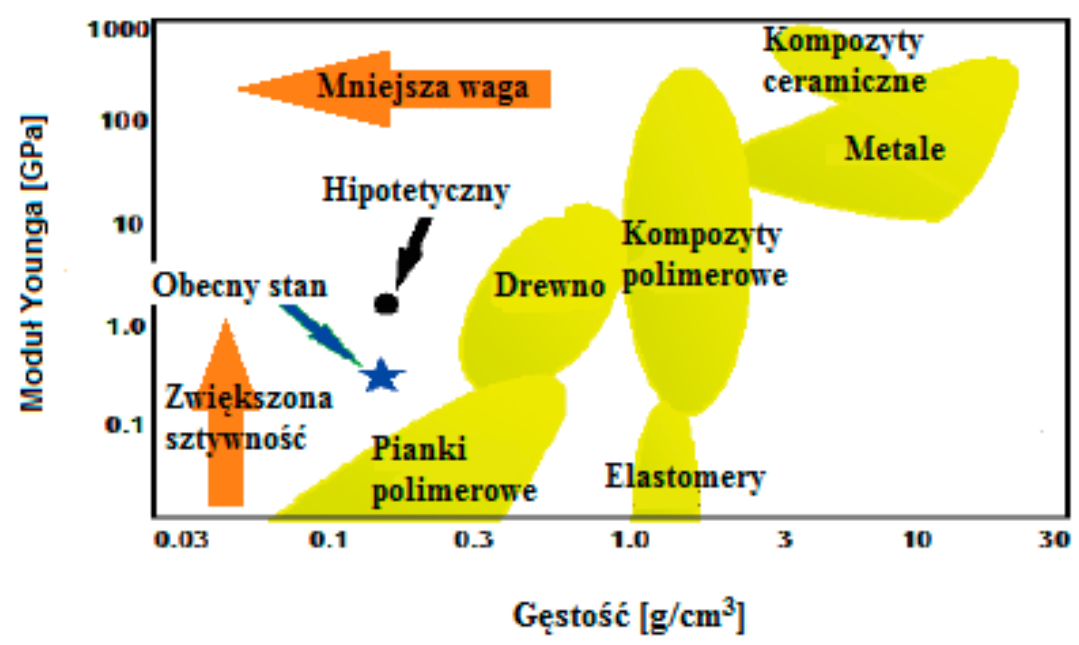

Ryc. 1. Porównanie właściwości materiału opartego na piance węglowej z innego rodzaju materiałami [4] 


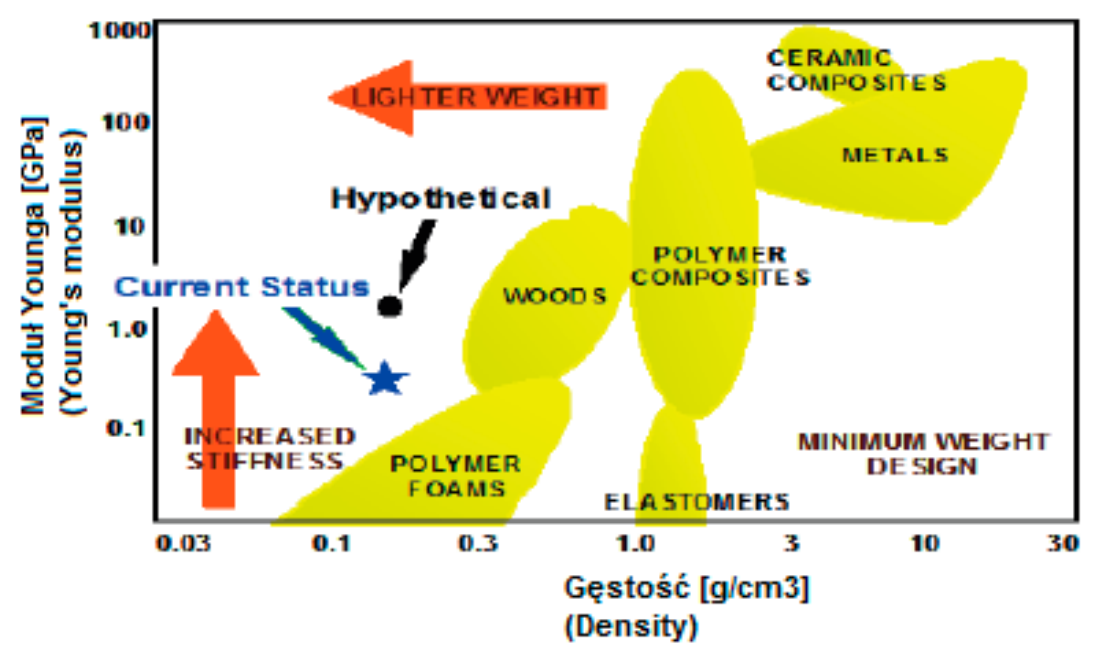

Fig. 1. A comparison of properties for carbon foam based materials with other materials [4]

Niniejsze badania numeryczne oraz eksperymentalne miały na celu zbadanie oraz predykcję aspektów wykorzystania materiału w postaci pianki węglowej jako alternatywnego materiału konstrukcyjnego hełmu wykorzystywanego w ochronie przeciwpożarowej.

Na potrzeby analizy zbadano kilka rodzajów pianki węglowej różniących się porowatością, gęstością, grubością oraz przewodnością cieplną. Analiza przeprowadzona została zgodnie z wytycznymi zawartymi w normach NFPA. $\mathrm{W}$ odniesieniu do testów wytrzymałości na oddziaływania mechaniczne norma stanowi, że półkulisty element przenoszący obciążenie opuszczany jest na głowę manekina $\mathrm{z}$ odpowiednio założonym hełmem. Siła przenoszona na głowę manekina poprzez hełm musi być mniejsza aniżeli 3780 N. Na potrzeby badania zbudowany został odpowiedni model 3D, natomiast obliczenia symulacyjne wykonane zostały za pomocą dynamicznego, jednoznacznego solvera Abaqus CAE. Poniżej przedstawiono siatkę geometryczną modelu badawczego oraz model geometryczny dla badania wytrzymałości na oddziaływanie mechaniczne.

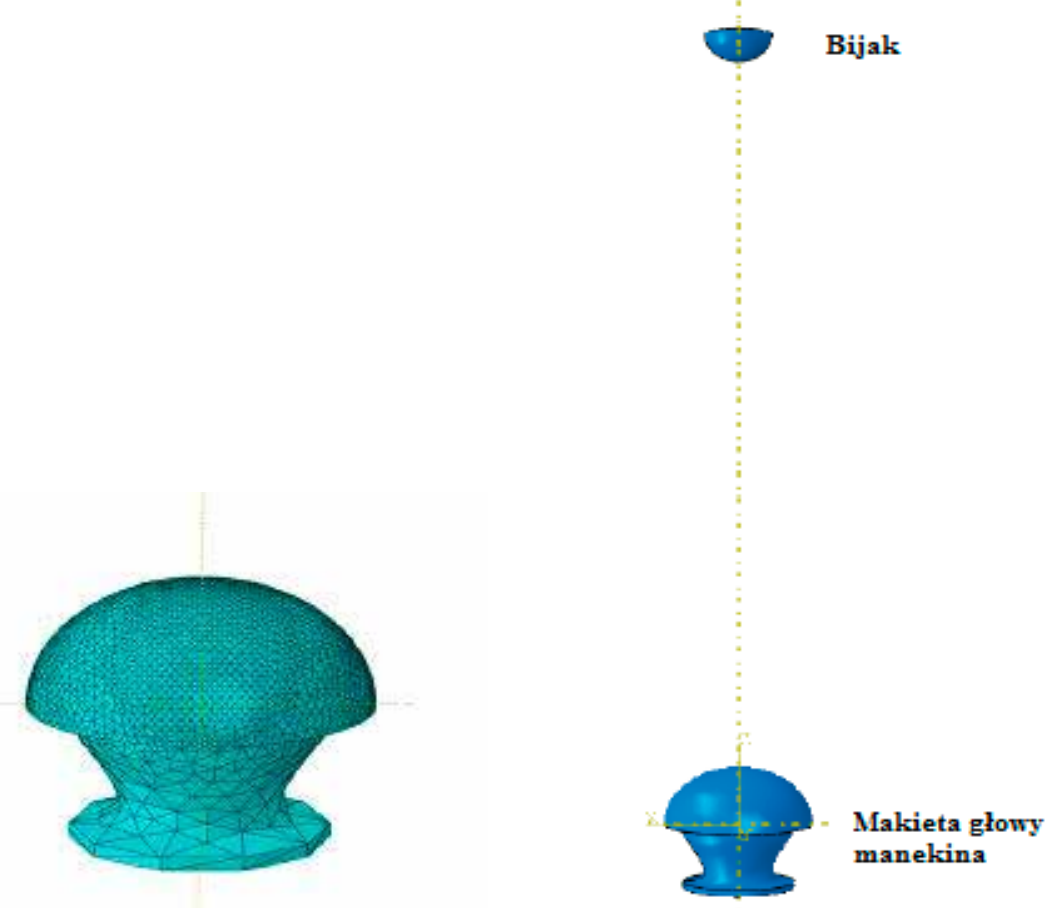

Ryc. 2. Siatka geometryczna modelu badawczego i model geometryczny dla badania wytrzymałości [4]

Fig. 2. Geometric grid of research model and geometric model for strength tests [4]

Model numeryczny został poddany weryfikacji oraz walidacji poprzez porównanie wyników jego symulacji z wynikami doświadczalnymi Rizova. Na potrzeby konstrukcji skorupy hełmu wykorzystano materiały z pianki węglowej o właściwościach przedstawionych w tabeli 1.
Natomiast wkładka ochronna zaprojektowana została $\mathrm{z}$ materiału pianki węglowej o właściwościach przedstawionych w tabeli 2 . 
Tabela 1. Właściwości materiałów z pianki węglowej na skorupę hełmu Table 1. Material properties of carbon foam for the shell of the helmet

\begin{tabular}{|c|c|c|c|c|c|}
\hline $\begin{array}{c}\text { Porowatość } \\
\text { / Porosity }\end{array}$ & \begin{tabular}{|c|} 
Gęstość $\left[\mathrm{kg} / \mathrm{m}^{3}\right]$ pianki \\
ze stałym wiązaniem \\
o gęstości $1400 \mathrm{~kg} / \mathrm{m}^{3}$ \\
/ Density $\left[\mathrm{kg} / \mathrm{m}^{3}\right]$ of the \\
foam with solid ligament \\
density of $1400 \mathrm{~kg} / \mathrm{m}^{3}$ \\
\end{tabular} & $\begin{array}{c}\text { Gęstość }\left[\mathrm{kg} / \mathrm{m}^{3}\right] \text { pianki } \\
\text { ze stałym wiązaniem } \\
\text { o gęstości } 1200 \mathrm{~kg} / \mathrm{m}^{3} \\
\text { / Density }[\mathrm{kg} / \mathrm{m} 3] \text { of the } \\
\text { foam with solid ligament } \\
\text { density of } 1200 \mathrm{~kg} / \mathrm{m}^{3}\end{array}$ & $\begin{array}{c}\text { Moduł } \\
\text { Younga } \\
\text { / Young's } \\
\text { modulus } \\
{[\mathrm{MPa}]}\end{array}$ & $\begin{array}{c}\text { Współczynnik } \\
\text { Poissona } \\
\text { / Poisson's ratio }\end{array}$ & $\begin{array}{c}\text { Granica } \\
\text { Sprężystości } \\
\text { / Yield strength } \\
{[\mathrm{MPa}]}\end{array}$ \\
\hline 0,05 & 1330 & 1140 & 76710 & 0,33 & 187,96 \\
\hline 0,1 & 1260 & 1080 & 68850 & 0,33 & 173,35 \\
\hline
\end{tabular}

Źródło: Opracowanie własne na podstawie [4].

Source: Own elaboration based on [4].

Tabela 2. Właściwości materiałów z pianki węglowej na wkładkę ochronną

Table 2. Material properties of carbon foam for the protective liner

\begin{tabular}{|c|c|c|c|c|c|}
\hline $\begin{array}{c}\text { Porowatość / } \\
\text { Porosity }\end{array}$ & $\begin{array}{c}\text { Gęstość }\left[\mathrm{kg} / \mathrm{m}^{3}\right] \text { pianki } \\
\text { ze stałym wiązaniem } \\
\text { o gęstości } 1400 \mathrm{~kg} / \mathrm{m}^{3} / \\
\text { Density }[\mathrm{kg} / \mathrm{m} 3] \text { of the } \\
\text { foam with solid ligament } \\
\text { density of } 1400 \mathrm{~kg} / \mathrm{m}^{3} \text { ) }\end{array}$ & $\begin{array}{l}\text { Gęstość }\left[\mathrm{kg} / \mathrm{m}^{3}\right] \text { pianki } \\
\text { ze stałym wiązaniem } \\
\text { o gęstości } 1200 \mathrm{~kg} / \mathrm{m}^{3} \\
\text { / Density }[\mathrm{kg} / \mathrm{m} 3] \text { of the } \\
\text { foam with solid ligament } \\
\text { density of } 1200 \mathrm{~kg} / \mathrm{m}^{3}\end{array}$ & $\begin{array}{c}\text { Moduł } \\
\text { Younga } \\
\text { / Young's } \\
\text { modulus } \\
{[\mathrm{MPa}]}\end{array}$ & $\begin{array}{c}\text { Współczynnik } \\
\text { Poissona / } \\
\text { (Poisson's ratio) }\end{array}$ & $\begin{array}{c}\text { Granica } \\
\text { Sprężystości } \\
\text { / Yield strength) } \\
{[\mathrm{MPa}]}\end{array}$ \\
\hline 0,95 & 70 & 60 & 62,5 & 0,33 & 2,85 \\
\hline
\end{tabular}

Źródło: Opracowanie własne na podstawie [4].

Source: Own elaboration based on [4].

Głowa manekina $\mathrm{z}$ nałożonym hełmem o grubości netto równej $0,0165 \mathrm{~m}$ (skorupa 0,0015, wkładka 0,015) została obciążona półkolistym elementem o masie $3,53 \mathrm{~kg}$ oraz wysokości 1,53 m. Dla drugiego materiału (pianki ze stałym wiązaniem o gęstości $1400 \mathrm{~kg} / \mathrm{m}^{3}$, wkładka pianki ze stałym wiązaniem o gęstości $1200 \mathrm{~kg} / \mathrm{m}^{3}$ ) wyniki wskazują, że największa siła zmierzona na głowie manekina wyniosła $3542,12 \mathrm{~N}$, co oznacza wartość mniejszą aniżeli wynosi standard NFPA, o którym wspomniano wcześniej. Ponadto naprężenia Misesa wyniosły $1,025^{\star} 10^{8} \mathrm{~Pa}$ i były mniejsze aniżeli granica sprężystości badanego materiału. Ciężar netto hełmu wykonanego z pierwszego materiału wynosił 0,2702 $\mathrm{kg}$ w porównaniu do $0,6928 \mathrm{~kg}$, kiedy hełm wykonany był ze standardowych materiałów.

W przypadku wykorzystania wkładki ochronnej z pianki węglowej zbadano również drugi materiał (pianka ze stałym wiązaniem o gęstości $1200 \mathrm{~kg} / \mathrm{m}^{3}$, wkładka pianki ze stałym wiązaniem o gęstości $1200 \mathrm{~kg} / \mathrm{m}^{3}$ ).

Porównując wyniki dla pierwszego oraz dla drugiego przypadku, zauważono znaczny spadek maksymalnej siły jaka występowała na głowie manekina. $Z$ drugiej strony wartość naprężenia szczytowego wzrosła w drugim przypadku. Masa hełmu dla drugiego przypadku wyniosła 0,2318 kg.

W kolejnym kroku zbadano hełm o grubości 0,0165 i takich samych parametrach jak miało to miejsce w pierwszym przypadku. Dla tego przypadku wartość szczytowej siły wyniosła $3262,36 \mathrm{~N}$, ponadto szczytowe naprężenie wyniosło $1,32^{\star} 10^{8} \mathrm{~Pa}$, co oznacza wartość mniejszą aniżeli granica sprężystości równa $1,7335^{\star} 10^{8} \mathrm{~Pa}$. Masa netto hełmu wyniosła 0,2992 kg.

Następnie w ramach analizy przeprowadzono badanie odporności na działanie płomienia zgodnie z normą NFPA.
Zgodnie z normą skorupę hełmu poddano działaniu płomienia o temperaturze $1300 \mathrm{~K}$ przez 15 sekund.

Symulacje numeryczne zostały wykonane za pomocą oprogramowania Fluent CFD z implikowanym solverem podwójnej precyzji opartym na ciśnieniu, pod warunkami nieustalonymi/stanu przejściowego. Efekt płomienia zaprojektowany został poprzez dostarczenie ciepła do skorupy hełmu zarówno w formie promieniowania, jak i konwekcji. Analiza polegała na jednokierunkowym monitorowaniu spadku temperatury na grubości hełmu. Walidacji modelu numerycznego dokonano poprzez porównanie z wynikami doświadczalnymi przez Songa.

W czwartym przypadku grubość netto hełmu wynosiła 0,0165, porowatość skorupy i wkładki odpowiednio 0,05 i 0,95. Przewodność cieplna pianki węglowej wyniosła $0,22 \mathrm{~W} / \mathrm{m}^{\star} \mathrm{K}$. Gęstość pianki ze stałym wiązaniem wyniosła $1400 \mathrm{~kg} / \mathrm{m}^{3}$. Hełm poddany był oddziaływaniu płomienia o temperaturze $1473 \mathrm{~K}$ przez 15 sekund.

Dla czwartego przypadku zaobserwowano spadek temperatury wzdłuż grubości przekroju hełmu, z $1104 \mathrm{~K}$ na zewnętrznej krawędzi skorupy, do $300 \mathrm{~K}$ na wewnętrznej krawędzi wkładki ochronnej.

W kolejnym analizowanym wariancie grubość hełmu wynosiła 0,0165. Porowatość pianki węglowej w skorupie hełmu o grubości 0,0015 wynosiła 0,05 , natomiast porowatość pianki węglowej wkładki ochronnej o grubości 0,015 była równa 0,95 .

Celem metody doświadczalnej było monitorowanie siły przenoszonej na tensometr przez powierzchnię pianki węglowej podczas zadanego oddziaływania bijaka. Badanie wpływu niskiej prędkości przeprowadzone zostało za pomocą swobodnie spadającego elementu z bardzo niskiej, 
pionowej wysokości na powierzchnię pianki węglowej umieszczonej na komórce tensometrycznej.

Do badań wykorzystano prostokątną płytę o wymiarach $0,223 \mathrm{~m}$ i 0,19 $\mathrm{m}$ wykonaną $\mathrm{z}$ pianki węglowej o grubości 0,006. Próbka podlegała oddziaływaniu stalowej iglicy w kształcie dysku o średnicy 0,09 m, grubości 0,006 m oraz wadze $0,211 \mathrm{~kg}$. Pianka węglowa posiadała gęstość nominalną równą $320 \mathrm{~kg} / \mathrm{m}^{3}$, porowatość równą $0,83 \mathrm{oraz}$ Moduł Young dla ściskania równy $620 \mathrm{MPa}$.

Wysokość spadku elementu oddziałującego została ustalona na $0,047 \mathrm{~m}$ od górnej powierzchni próbki z pianki węglowej. Badanie przeprowadzone zostało 3 razy.

Dane rejestrowane były przy częstotliwości $2000 \mathrm{~Hz}$. Wykres siły nacisku zarejestrowanej w czasie oddziaływania został przedstawiony na rycinie 3 .

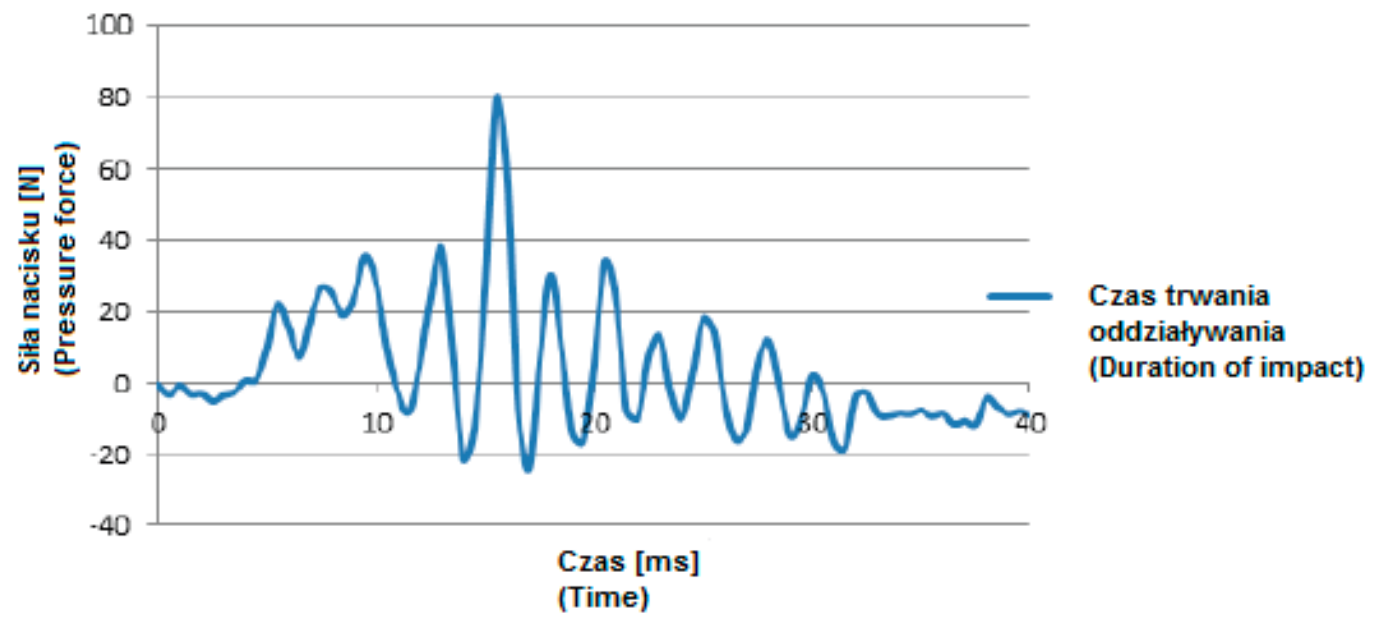

Ryc. 3. Siła nacisku w czasie oddziaływania

Fig. 3. Total pressure at the time of impact

Źródło: Opracowanie własne na podstawie [4]. Source: Own elaboration based on [4].

Charakter wykresu przedstawionego na rycinie jest podobny do uzyskanych wyników podczas analizy numerycznej z wykorzystaniem oprogramowania Abaqus. Stały spadek i wzrost siły nacisku wynika z porowatości oraz właściwości absorbujących materiału pianki węglowej.

Wyniki różnych symulacji przedstawionych powyżej wskazują, iż pianka węglowa o zaproponowanych właściwościach jest w stanie zapewnić wymaganą ochronę dla głowy strażaka przed oddziaływaniami mechanicznymi oraz termicznymi. Masa netto dzięki wykorzystaniu badanego materiału może ulec zmniejszeniu o $57-61 \%$ w stosunku do standardowych materiałów wykorzystywanych do produkcji hełmów strażackich.

Pianka węgla powoduje, iż hełm strażacki może być bardzo lekkim narzędziem pracy, zwiększając poziom komfortu użytkownika, dodatkowo zapewniając wymaganą ochronę oraz trwałość.

\section{Analiza możliwości podniesienia poziomu bezpieczeństwa gwarantowanego przez hełmy strażackie $w$ ramach ochrony przeciwpożarowej zbliżeniowej [5-6]}

Minimalne wymagania odnośnie ochrony przeciwpożarowej określone zostały przez National Fire Protection Association (NFPA) w odpowiednich normach w tym dotyczących hełmów strażackich. Szczególne znaczenie mają regulacje odnoszące się do tak zwanej ochrony przeciwpożarowej zbliżeniowej, gdzie praca odpowiednich służb narażona jest na promieniowanie cieplne będące wynikiem pożarów pędnych w bezpośredniej odległości.
Standardy znajdujące się w odpowiednich normach stanowią, że temperatura wewnętrznej powierzchni skorupy hełmu strażackiego będącego częścią ubioru ochronnego, poddana strumieniowi promieniowania cieplnego o natężeniu $1 \mathrm{~W} / \mathrm{cm}^{2}$ na zewnętrznej powierzchni przez 3 minuty, nie wzrośnie więcej aniżeli $25^{\circ} \mathrm{C}$. Standard ten powstał w celu zaprzestania uwzględniania elementów izolacyjnych hełmu i skupienia się wyłącznie na zewnętrznej skorupie hełmu oraz na wszelkich zewnętrznych pokryciach na zewnętrznej skorupie.

Zgodnie z zapisami norm NFPA odnośnie hełmów wykorzystywanych do ochrony przeciwpożarowej zbliżeniowej dopuszcza się wykorzystywanie tradycyjnych hełmów ochrony strukturalnej pod warunkiem, że są one wyposażone w wymienne osłony $\mathrm{z}$ włókien pokrytych aluminium lub okrycia (okrycie przyczepiane do skorupy hełmu strażackiego wykonane $\mathrm{z}$ tkanin włókienniczych o szorstkiej powierzchnii z dużą ilością małych splotów). Tego typu podejście pozwala na dostarczenie odpowiedniej ochrony termicznej, jednak posiada również kilka wad. Po pierwsze okrycia muszą zostać zainstalowane na powłoce hełmu przed użyciem. Tego typu instalacja może być trudna oraz czasochłonna, co biorąc pod uwagę, że działania związane z ochroną przeciwpożarową zazwyczaj są pilne, jest znaczącym utrudnieniem. Ponadto w związku z tym, że okrycia nie są integralną częścią hełmu istnieje ryzyko ich zaczepienia o przeszkody lub nawet całkowitego oderwania. Tego typu zakłócenia mogą zagrażać odpowiedniej ochronie hełmu. Ponadto biorąc pod uwagę, że okrycia wykonane są z tkanin tekstylnych, ich powierzchnie są szorstkie co może powodować zatrzymywanie na powierzchni hełmu 
sadzy i innych zanieczyszczeń. Nagromadzenie tego typu zanieczyszczeń może znacząco zmniejszyć współczynnik odbicia promieniowania cieplnego powierzchni hełmu.

Niektóre badania wskazują, że metalowe powłoki próżniowo metalizowane do zewnętrznej powierzchni hełmu ochrony strukturalnej mogą w znaczący sposób wpływać na zmniejszenie współczynnika absorpcji skorupy. Wadą tego rodzaju powłok jest ich znaczna kruchość, na co wskazuje rozwarstwienie powłoki metalowej z podłoża hełmu. Rozwiązaniem pozwalającym na zwiększenie trwałości powłok są tak zwane powłoki ochronne, których wadą jest jednak wpływ na zwiększenie współczynnika absorpcji powierzchni hełmu. Wyzwaniem dla badaczy było stworzenie powłok, które zapewniałyby odpowiednio wysoki współczynnik odbicia promieniowania cieplnego oraz będących odpowiednio wytrzymałymi na uderzenia oraz siły ścierania. Wykonano analizy, jak również badania zgodnie $\mathrm{z}$ wymaganiami zawartymi w normach NFPA, mające na celu ocenę materiałów pod względem współczynnika odbicia promieniowania cieplnego oraz odporności na zniszczenie pod wpływem ścierania mechanicznego. Odpowiednio przygotowane próbki materiałów poddane zostały oddziaływaniu źródeł promieniowania cieplnego w zakresie temperatur od 700 do $1000 \mathrm{~K}$. Tego typu zakres temperatury, według założeń odpowiada rzeczywistym warunkom, jakie mogą wystąpić podczas akcji gaśniczej.

Istnieje wiele różnego rodzaju czynników, które należy uwzględnić przy projektowaniu hełmów strażackich. Ponadto należy pamiętać, że istnieje wiele aspektów, które odróżniają specjalistyczne hełmy wykorzystywane do ochrony strukturalnej (system ochrony przeciwpożarowej w budynku, statku lub innym obiekcie pływającym na morzu obejmujący: aktywną ochronę przecipożarową, pasywną ochronę przeciwpożarową oraz prewencję), ochrony lotniczej itd. Z drugiej strony należy zauważyć, że istnieje pewien zbiór elementów, które są wspólne dla wszystkich rodzajów ochrony przeciwpożarowej. Do tych elementów należą: komfort użytkowników, masa, stabilność, odpowiednie dopasowanie oraz cały zbiór zagadnień związanych z ochroną przed obciążeniami cieplnymi, mechanicznymi, jak również elektrycznymi. Ponadto hełm musi być wyposażony w maskę chroniącą twarz i/lub gogle mające na celu ochronę oczu użytkownika, jak również elementy mające na celu ochronę uszu oraz szyi. Hełmy muszą również zapewnić odpowiednią przestrzeń w celu przyłączenia maski z tlenem oraz urządzeń telekomunikacyjnych.

Projekt hełmu na potrzeby zbliżeniowej ochrony przeciwpożarowej, oprócz wyżej wymienionych ogólnych kryteriów, powinien również spełniać dodatkowe specyficzne warunki. Spowodowane jest to w szczególności częstym oraz bliskim kontaktem z płomieniem o wysokiej temperaturze, a tym samym znaczącymi wielkościami promieniowania cieplnego. Zabezpieczenia wymagane w strukturalnej ochronie przeciwpożarowej mogą nie wystarczyć do ochrony użytkownika przed tak dużymi wielkościami strumienia promieniowania cieplnego. Podobnie wygląda sytuacja dla hełmu będącego częścią ubioru ochrony przeciwpożarowej strukturalnej. W przypadku tego typu hełmu może dojść do jego uszkodzenia mechanicznego w ciągu kilku minut ze względu na bardzo szybką absorbcję ciepła promieniowania przez skorupę. Promieniowanie cieplne występujące podczas akcji ochrony przeciwpożarowej zbliżeniowej może bardzo szybko doprowadzić do degradacji sprzętu ochronnego w tym hełmie. Należy zatem tak projektować hełmy strażackie z materiałów z możliwie najniższym współczynnikiem absorpcji oraz możliwie najwyższym współczynnikiem odbicia promieniowania cieplnego. Obecnie tworzywami, które wykorzystywane są do wytworzenia osłon oraz okryć hełmów są materiały włókiennicze $\mathrm{z}$ włókien poliamidu aromatycznego $\mathrm{z}$ folią aluminiową dołączoną do tkaniny. Technologia ta została opracowana w latach 50 . XX wieku i w praktycznie nie zmienionej postaci jest wykorzystywana do dzisiaj. Aluminium wykorzystywane jest w wytwarzaniu okryć z kilku powodów: po pierwsze właściwości fizyczne pozwalają na łatwe formowanie w cienkie warstwy oraz łączenie ich z materiałami tekstylnymi za pomocą klejów. Aluminium charakteryzuje się również stosunkowo niską gęstością, co wpływa na obniżenie ciężaru gotowego produktu. Ponadto aluminium w wypolerowanej, utlenionej postaci posiada współczynnik odbicia promieniowania cieplnego większy aniżeli większość metali, stały w szerokim zakresie długości fal widmowych. Ostatnią istotną zaletą aluminium jest jego stosunkowo niska cena, szczególnie w porównaniu $\mathrm{z}$ innymi materiałami.

Tekstylne okrycia $\mathrm{z}$ dodatkiem aluminium posiadają jednak również wady. Po pierwsze okrycia wytworzone z tego typu materiałów mają nietrwały charakter. Zadaniem okrycia jest pokrycie skorupy hełmu, ponadto hełmy muszą posiadać możliwość zakładania oraz zdejmowania okrycia ze skorupy hełmu w celu konserwacji, czyszczenia oraz odkażania. Zakładanie ich może być jednak trudne oraz czasochłonne, jak już wcześniej wspomniano. Ponadto $\mathrm{z}$ uwagi na wykonanie $\mathrm{z}$ tkanin tekstylnych zawierają wiele drobnych szczelin, do których dostać mogą się liczne zanieczyszczania. W miarę gromadzenia się zanieczyszczeń w szczelinach maleje współczynnik odbicia promieniowania cieplnego, a tym samym skuteczność ochrony przeciwpożarowej. Tego typu zanieczyszczenia mogą zostać usunięte poprzez odpowiednie szczotkowanie i/lub pranie, jednak powtarzanie tego typu procesów powoduje niszczenie powłoki aluminiowej na podłożu tekstylnym, w sposób stały degradując materiał oraz obniżając poziom gwarantowanego bezpieczeństwa. Ponadto jak wcześniej wspomniano pokrycia nie są trwale montowane do skorupy hełmu, dlatego też istnieje ryzyko ich oderwania oraz narażenia użytkowania na utratę ochrony przeciwpożarowej. Dodatkowo urazy mechaniczne, w tym przede wszystkim otarcia, mogą powodować odrywanie powłoki aluminiowej $\mathrm{z}$ materiału oraz utratę jego właściwości ochronnych.

Odpowiedni projekt hełmu wymaga zarówno analizy ilościowej, jak i jakościowej. Analiza ilościowa może zostać przeprowadzona za pomocą narzędzi analitycznych, symulacji komputerowych, jak również doświadczeń. $Z$ kolei analiza jakościowa wykonana może zostać z wykorzystaniem ankiet użytkowników oraz istniejących na rynku benchmarków (punktów odniesienia). Odpowiednie dane niezbędne do analizy jakościowej mogą zostać zaczerpnięte 
z regulacji oraz norm NFPA. Należy zauważyć, że brak jest regulacji prawnych, które stanowiłyby o konieczności stosowania norm NFPA, jednak przeważająca liczba instytucji wymaga, aby odzież ochronna w tym hełmy spełniała te wymagania. Normy bezpieczeństwa (NFPA 1976-2000: Protective Ensemble for Proximity Fire Fighting) w przypadku hełmów strażakich definiują minimalne poziomy gwarantowanego bezpieczeństwa w odniesieniu do sił tłumienia, odporności na fizyczną penetrację, deformacje fizyczne, niepalność, izolację elektryczną, zatrzymywanie elementów, korozję elementów metalowych, trwałość etykiet oraz czytelność i przepuszczalność promieniowania cieplnego. Niektóre fragmenty norm nie są jednak wystarczające. Jedna z sekcji mówi o dopuszczalnej wielkości promieniowania, jaka może być transmitowana przez panel radiacyjny w kierunku hełmu strażackiego. Wielkość podana w normie wynosi od 1 do $0,1 \mathrm{~W} / \mathrm{cm}^{2}$. Zakres podany w normie jest właściwy, jednak jego rozpiętość jest duża i nie wskazuje jasno na sytuację, jaka może wystąpić podczas akcji gaśniczej. W szczególności standard nie uwzględnia zmienności widma promieniowania. Standard definiuje wielkość strumienia ciepła promieniowania, jednak nie uwzględnia rodzaju źródła promieniowania. Ponadto normy nie uwzględniają odporności skorupy lub powłoki skorupy na działanie sił ścierających. Dla hełmów, które nie są narażone na działanie bardzo wysokich temperatur, jakiekolwiek skazy powierzchni nie stanowią problemu, jednak w przypadku hełmów ochrony zbliżeniowej tego typu niedoskonałości mogą mieć znaczący wpływ na obniżenie poziomu gwarantowanego bezpieczeństwa.
Biorąc pod uwagę charakter pracy związanej z ochroną przeciwpożarową, niezbędne jest, aby hełmy były również odporne na uszkodzenia mechaniczne.

Największy potencjał poprawy poziomu bezpieczeństwa gwarantowanego przez hełmy strażackie związany jest z nowymi technologiami wytwarzania skorupy hełmu, które eliminowałyby lub zmniejszały wymienione wyżej wady materiałów tekstylnych z powłoką aluminiową. Projektując nowe rozwiązania, należy uwzględnić dwa najważniejsze czynniki: wysoki współczynniki odbicia promieniowania cieplnego dla określonego spektrum promieniowania oraz odporność powierzchni na uszkodzenia. Normy stworzone przez NFPA stanowią odniesienie oraz benchmark dla hełmów ochrony przeciwpożarowej. Jednak projektując tego typu hełm, należy również zwrócić uwagę na zmianę temperatury skorupy pod wpływem zmieniających się długości fal promieniowania w zakresie, który odpowiadałby rzeczywistym warunkom panującym w czasie akcji przeciwpożarowych. Odpowiednio zdefiniowane powinny być również metody pomiaru trwałości oraz odporności na uszkodzenia.

Należy zauważyć, że istnieje niewiele standardów przemysłowych i metod badawczych pozwalających na analizę poziomu bezpieczeństwa gwarantowanego przez powierzchnie hełmu strażackiego. Badanie skoncentrowane zostało na ocenie trwałości, jak również współczynnika odbicia promieniowania cieplnego próbek skorup hełmu. Badania przeprowadzone zostały dla zakresu temperatur od 700 do $1000 \mathrm{~K}$.

Stworzone zostało stanowisko do pomiaru emisyjności materiału dla różnych długości fal promieniowania cieplnego. Schemat stanowiska badawczego przedstawiono poniżej.

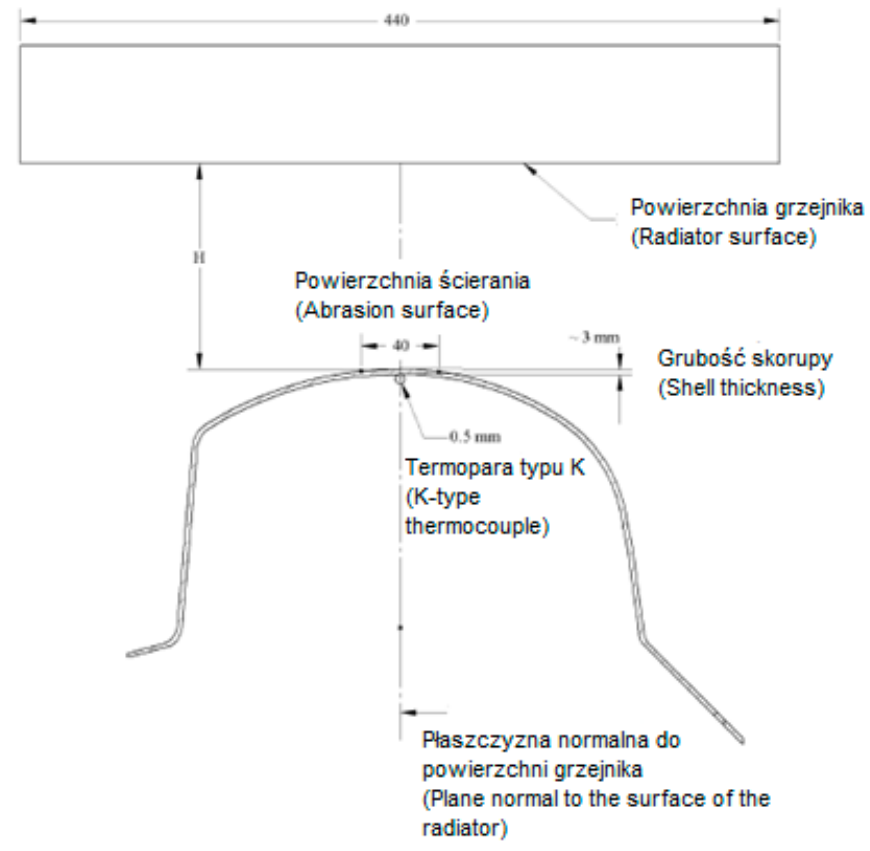

Ryc. 4. Schemat stanowiska badawczego

Fig. 4. Scheme of the test bench

Źródło: Opracowanie własne na podstawie [5].

Source: Own elaboration based on [5].

Stanowisko składa się z źródła promieniowania cieplnego w postaci ciała doskonale czarnego, zasilanego elektrycznie. Skorupa hełmu utrzymywana jest w odpowiednim położeniu, a pomiar temperatury wykonywany jest za pomocą termopar przymocowanych do wewnętrznej powierzchni skorupy. 
Zadaniem źródła ciepła było emitowanie promieniowania cieplnego analogicznego do tego jakie występuje w rzeczywistych warunkach ochrony przeciwpożarowej, przy równoczesnym zachowaniu odpowiedniego poziomu bezpieczeństwa. Źródło powinno posiadać niemal czarną powierzchnię (emisyjność zbliżona do $1.0 \mathrm{w}$ szerokim zakresie widma) oraz utrzymywać temperaturę na powierzchni, jedynie z niewielkimi odchyleniami, tak aby strumień promieniowania cieplnego był stały, zarówno w odniesieniu do wielkości, jak i charakteru widma. Źródłem ciepła $\mathrm{w}$ przedstawiany badaniu był grzejnik elektryczny o mocy $5 \mathrm{~kW}$ oraz wymiarach $30 \mathrm{~cm} \mathrm{x} 45 \mathrm{~cm}$. Grzejnik zasilany by prądem trójfazowym o natężeniu $10 \mathrm{~A}$ oraz napięciu $480 \mathrm{~V}$. Powierzchnia grzejnika osiągała maksymalną temperaturę powyżej $1000 \mathrm{~K}$. System sterowania w zamkniętej pętli wykorzystany został do sterowania oraz stabilizacji temperatury. Termopara typu K została umieszczona w kontakcie z powierzchnią grzejnika oraz połączona z elektronicznym termostatem, podłączonym do stycznika.

Ważnym elementem stanowiska badawczego było urządzenie, które pozwalało na szybkie dostarczenie próbki do źródła promieniowania, utrzymania próbki przez określony czas oraz szybkie usunięcie jej z obszaru promieniowania. $\mathrm{W}$ ramach tego procesu mierzona była temperatura wewnętrznej powierzchni skorupy hełmu oraz otaczającego ją powietrza.

Metoda pomiaru temperatury była zgodna $\mathrm{z}$ wymaganiami znajdującymi się w normach NFPA. Temperatura wewnętrznej powierzchni skorupy była mierzona za pomocą termopary typu K bezpośrednio poniżej punktu maksymalnego strumienia promieniowania cieplnego (wykorzystano miedzianą folię do mocowania termopary). Poprzez pomiar temperatury na wewnętrznej powierzchni skorupy można było pośrednio oszacować ilość zaabsorbowanego ciepła przez skorupę o grubości około $3 \mathrm{~mm}$. Mimo, że pomiar nie odbywał się w sposób bezpośredni, jego zaletami była powtarzalność oraz prostota. Wielkość strumienia ciepła w czasie przeprowadzania pomiarów różnego rodzaju skorup równa była $1 \mathrm{~W} / \mathrm{cm}^{2}$, a pomiar trwał 180 sekund.

Zgodnie $\mathrm{z}$ wymogami normy NFPA do odpowiedniego punktu na zewnętrznej powierzchni skorupy przyłożony był strumień promieniowania cieplnego o wartości $1,0 \mathrm{~W} / \mathrm{cm}^{2}$. Dysponując informacjami na temat wymiarów powierzchni promieniowania, jej emisyjności oraz jej profilu temperatury, można było określić teoretyczny strumień ciepła w określonych punktach skorupy hełmu. Z kolei bezpośredni pomiar rzeczywistego strumienia ciepła odbywał się za pomocą radiometru.

Podczas pomiarów, strumień promieniowania ciepła był stały, zmieniła się jednak temperatura grzejnika. Jak wiadomo długość fali promieniowania cieplnego jest odwrotnie proporcjonalna do temperatury źródła zgodnie z prawem Wiena. Podczas pomiarów zaobserwowano zależność pomiędzy długością fal promieniowania cieplnego a temperaturą skorupy hełmu. Ze względu na to, że ilość pochłanianego ciepła promieniowania zależy proporcjonalnie od absorpcyjności ciała, zaobserwowane wzrosty temperatury powierzchni skorupy skorelowano z absorpcyjnością poszczególnych próbek. Biorąc pod uwagę powyższe informacje, zaobserwowano również związek pomiędzy względną absorpcyjnością a długością fali padającego promieniowania cieplnego. Dzięki badaniu określone zostały względne absorpcyjności widmowe dla poszczególnych próbek.

Drugą bardzo istotną częścią badania było określenie odporności na zniszczenie poszczególnych próbek w szczególności na ścieranie. W związku z brakiem odpowiednich norm i standardów pozwalających na określenie tego typu wielkości, badanie zostało oparte na doświadczenia zebranych $\mathrm{w}$ akcjach gaśniczych oraz analizie zagrożeń, jakie mogą wystąpić podczas tego typu akcji. Inspekcje hełmów noszonych podczas akcji ochrony przeciwpożarowej wkazywały na częste uszkodzenia hełmów w związku z otarciami i lekkimi uderzeniami.

Stanowisko badawcze zostało zainspirowane protokołem badania oceny odporności na zarysowania komponentów optycznych. Badanie polegało na określeniu wytrzymałości hełmu na otarcia od obiektu o znanej chropowatości powierzchni, pod znaną siłą dla określonej liczby powtórzeń. Na potrzeby badania zbudowane zostało stanowisko badawcze, które składało się z bloku montażowego, szyn ślizgowy przegubowych, cylindra pneumatycznego z zamocowanym papierem ściernym oraz miernika ciśnienia powietrza do monitorowania siły przyłożonej do próbek. Podczas badania papier ścierny (ziarna o wielkości $100 \mathrm{mi}$ krometrów) dokonywał szlifowania skorupy próbki przy użyciu siły równej $60 \mathrm{~N}$. Każda próbka poddawana była szlifowaniu 5 razy. Następnie miało miejsce porównanie dla poszczególnych materiałów.

Po przeprowadzonym badaniu na wytrzymałość przed ścieraniem próbki poddawane były kolejnemu badaniu odporności na promieniowanie cieplne. Dzięki temu można było określić wpływ ścierania próbki na jej współczynnik odbicia promieniowania cieplnego

W badaniu wykorzystane zostało 9 próbek, wśród których 2 miały zastosowanie komercyjne, a w badaniu użyte zostały jako punkty odniesienia. Pierwsza próbka referencyjna była formowana z tworzywa termoplastycznego. Druga była skorupą okrytą poryciem z materiału tekstylnego z osłoną aluminiową. Pozostałe próbki były eksperymentalnymi skorupami z modyfikowaną konstrukcją kompozytów. Każda z tych próbek była wykonana z materiału jak pierwsza próbka referencyjna jednak $z$ dodatkowymi powłokami na zewnętrznej powierzchni. Powłoki były wykonane z tytanu metalizowanego próżniowo, miedzi elektrolitycznej, powlekanej rozpylaną cyną, aluminium metalizowanym próżniowo, pylistego aluminium, oraz stopu galwanicznego nikiel-chrom.

Na potrzeby badania wykonana została dogłębna analiza literatury, jednak jak stwierdzono występuje bardzo niewiele informacji na temat badań wytrzymałościowych hełmów strażackich. Znacznie więcej informacji dostępnych jest na temat spalania, jak również zjawisk pożarowych. Jak wykazują badania dla pożarów większych aniżeli 0,3 $\mathrm{m}$ (powierzchnia pożaru nie jest większa niż $0,3 \mathrm{~m} \mathrm{x} 0,3 \mathrm{~m}$, a wysokość ognia nie większa niż $0,3 \mathrm{~m}$ ), wymiana ciepła zdominowana jest przez promieniowanie cieplne. Tego 
typu promieniowanie spowodowane jest przede wszystkim przez promieniowanie cieplne cząstek sadzy. Najwyższe temperatury, jakie mają miejsce podczas pożarów, mogą wynosić około $1250 \mathrm{~K}$. Strumień promieniowania ciepła, jaki jest wynikiem tego typu pożarów, równy jest zazwyczaj około 2,0 W/ $/ \mathrm{cm}^{2}$.

Badaniu podlegały materiały nieprzezroczyste, dlatego wymiana ciepła na drodze promieniowania analizowana była jako zjawisko powierzchniowe. Należy zaznaczyć, że współczynnik odbicia promieniowania powierzchni metalicznych lub powłok jest silnie uzależniony od cech chemicznych oraz obróbki mechanicznej badanej powierzchni. Właściwości próżniowo osadzanych mechanicznych powierzchni różnią się znacząco od powierzchni metali wykańczanych lub polerowanych. Te pierwsze charakteryzują się większymi współczynnikami odbicia.

W celu lepszego zrozumienia zjawisk wymiany ciepła występujących podczas przeprowadzanych badań i oceny wyników eksperymentalnych zbudowano 2 modele (jednowymiarowe) analityczne wymiany ciepła. Pierwszy oparty został o stały strumień ciepła ustawiony na zewnętrznej powierzchni skorupy. Drugi opracowano z myślą o dokładniejszym odwzorowaniu rzeczywistych warunków wymiany ciepła na drodze promieniowania podczas przeprowadzania doświadczeń. Geometria skorupy hełmu składa się ze złożonych, trójwymiarowych zakrzywionych powierzchni, stąd też nie mogła być w całości, w dostatecznie dokładny sposób, opisana za pomocą równań analitycznych. Biorąc pod uwage jedynie punkty maksymalnego strumienia promieniowania cieplnego, nieskończenie małe elementy w punktach najbliższych panelu radiacyjnego mogły być odpowiednio ocenione i dzięki temu zbudowany model jednowymiarowy reprezentujący odpowiednio dokładnie wymianę ciepła. Modele analityczne zostały zbudowane przy uwzględnieniu jedynie elementów różnicowych na górnej powierzchni skorupy hełmu w wykorzystywanych równaniach wymiany ciepła (równanie Fouriera).

W pierwszym modelu analitycznym stały strumień ciepła został określony na poziomie równym $1 \mathrm{~W} / \mathrm{cm}^{2}$ na zewnętrznej powierzchni skorupy. Przyjęto, że właściwości termiczne skorupy są jednorodne oraz stałe. Oddziaływanie wymiany ciepła na drodze konwekcji zostało pominięte, a wewnętrzna powierzchnia skorupy została przyjęta jako adiabatyczna.

Z kolei w drugim modelu uwzględniona została wymiana ciepła na drodze promieniowania oraz szczegółowy układ stanowiska badawczego. Geometria została ustalona w ten sposób, że element różnicujący był skierowany bezpośrednio pod panelem radiacyjnym w zmiennej odległości, tak jak miało to miejsce w rzeczywistości. Założono brak występowania zjawiska radiacji z powierzchni skorupy do otoczenia. Właściwości termiczne skorupy założono jako jednorodne oraz stałe. Oddziaływanie wymiany ciepła na drodze konwekcji zostało pominięte, a wewnętrzna powierzchnia skorupy została przyjęta jako adiabatyczna.

W modelach założono, że emisyjność oraz absorpcyjność próbek mają charakter zmienny wraz ze zmianą długości fali promieniowania cieplnego. Z kolei kierunek promieniowania w doświadczeniach był stały dlatego zmiana nie został uwzględniona w modelach. Biorąc pod uwagę, że większość promieniowania cieplnego powstałego w wyniku rzeczywistego pożaru stanowi promieniowanie sadzy w temperaturze $1400 \mathrm{~K}$, można było określić zakres widmowy promieniowania. Wykorzystując tabelę funkcji promieniowania ciała doskonale czarnego, określono odpowiedni zakres długości fal promieniowania, biorąc pod uwagę 80 procent całkowitej emisji jaka występuje w temperaturze $1400 \mathrm{~K}$. Otrzymany zakres długości fal wyniósł 1,6 do 6,7 $\mu \mathrm{m}$. Mając określony zakres długości fal, oszacowano dla niego wartości emisyjności oraz absorpcyjności. Podobny proces przeprowadzono dla temperatury $1000 \mathrm{~K}$, czyli takiej w jakiej w rzeczywistości odbywały się badania. Dokonując porównani zakresu długości fal, stwierdzono, że wyniki otrzymane w doświadczeniu mogą z wystarczającą dokładnością zostać przeniesione na warunki rzeczywiste.

Wyniki badania wykazały, że w zakresie widzialnego promieniowania dla badanych temperatur, występują niewielkie wahania absorpcyjności skorup hełmu strażackiego. Próbki wykazywały zwiększenie absorpcyjności w wyniku przeprowadzenia badania wytrzymałości przed ścieraniem, wyjątek im była jedynie pierwsza próbka referencyjna. Uwzględniając wytyczne norm NFPA, które stanowią, że wzrost temperatury wewnętrznej powierzchni skorupy nie może być większy aniżeli $25^{\circ} \mathrm{C}$, w przeciwnym wypadku hełm nie powinien być dopuszczony do użytkowania. Jak wykazały badania norma ta została spełniona jedynie dla materiały tekstylnego $\mathrm{z}$ powłoką aluminiową zarówno przed ścieraniem jak i po nim. W przypadku próbki próżniowo metalizowanej aluminium doszło do spełnienia normy jedynie przed ścieraniem, zarazem próbka ta wykazała najmniejszy wzrost temperatury przed procesem ścierania. Pozostałe próbki nie spełniły wymagań normy.

Na błędy pomiarów wpływać mogła oscylacja temperatury grzejnika w zakresie $30 \mathrm{~K}$. Innym powodem mogło być nieuwzględnienie konwekcyjnej wymiany ciepła w modelach.

Najlepsze wyniki dla próbki z materiału tekstylnego z osłoną aluminiową mogą być związane jego unikalną konstrukcją. Próbka ta była jedyną, w której miało miejsce połączenie niezintegrowanej powłoki z skorupą bazową. Charakter tego typu dwuczęściowego połączenia posiada przewagę w postaci zwiększonego oporu cieplnego w porównaniu do innych jednoczęściowych próbek. Połączenie osłony aluminiowej z podstawą powoduje, że materiał pokrywa luki pomiędzy tkaniną pokrycia a zewnętrzną powierzchnią skorupy hełmu, które stanowią dodatkową barierę wymiany ciepła.

Z kolei spadek temperatury po procesie ścierania dla pierwszej referencyjnej próbki może być wytłumaczony efektem powstawania bąbli w wyniku topnienia materiału, wykazywanym przez materiał termoplastyczny z jakiego wykonana była skorupa.

Wykonane badania, z racji niewielkiej ilości szeroko dostępnych danych eksperymentalnych, mogą być podstawą dla ewentualnych dalszych badań lub ich kontynuacji. Sugeruje się, że istnieje duży potencjał badawczy w szczególności w badaniu wpływu długości fal promieniowania cieplnego na wytrzymałość termiczną hełmów strażackich. 
Z powodu różnego rodzaju ograniczeń powyższe badania przeprowadzone zostały dla dość wąskiego zakres temperatur. Należy zauważyć, że w przypadku otwartych pożarów efektywna temperatura równa jest około $1400 \mathrm{~K}$, natomiast w niektórych przypadkach temperatura płomienia może być równa nawet $2400 \mathrm{~K}$. Dlatego też hełm strażacki może podlegać oddziaływaniu promieniowania o znacznie krótszych długościach fal. Analogicznie sytuacja wygląda jeżeli chodzi o wartość strumienia promieniowania cieplnego, który w rzeczywistych warunkach może osiągać wartości znacznie większe aniżeli $1 \mathrm{~W} / \mathrm{cm}^{2}$.

\section{Podsumowanie}

W powyższym artykule przedstawiono liczne informacje na temat metod oraz technologii wytwarzania odzieży ochronnej wykorzystywanych w Stanach Zjednoczonych na przykładzie hełmu strażackiego. W artykule dokonano przeglądu technologii wytwarzania hełmów strażackich o określonych własnościach, jak również tematyki związanej z możliwościami podniesienia poziomu bezpieczeństwa gwarantowanego przez hełmy strażackie.

\section{Wnioski}

Należy zauważyć, że dostępna literatura naukowa zawiera niewielką liczbę pozycji związanych z tematyką opracowania, opartych w znacznej mierze na amerykańskich normach National Fire Protection Association. Artykuł może więc stanowić znaczące źródło informacji, w szczególności w zakresie możliwości podniesienia poziomu bezpieczeństwa gwarantowanego przez hełmy strażackie wykorzystywanych w Stanach Zjednoczonych oraz porównania ich $\mathrm{z}$ europejskimi normami w tym zakresie (PN-EN 443).

Przytoczony w artykule eksperyment dotyczący uderzenia bijaka w skorupę hełmu z energią 54 J przy równoczesnym spełnieniu wymagania NFPA dotyczącego siły przenoszonej na głowę na poziomie max. $3,79 \mathrm{kN}$ posiada bardzo zbliżone parametry do obowiązujących w Polsce przed wejściem do Unii Europejskiej. Obecnie wymagania wynikające z normy europejskiej PN-EN 443 ustanowione zostały na innymi poziomie, tj. po uderzeniu bijaka w skorupę hełmu $\mathrm{z}$ energią $123 \mathrm{~J}$, siła przenoszona na głowę nie może przekroczyć 15 kN. Również proponowane rozwiązanie „tekstylnego pokrowca na hełm” mającego na celu wzrost jego odporności na promieniowanie cieplne nie może zostać przyjęte w kraju. Hełm strażacki wyposażony w tego typu pokrowiec nie przeszedłby badań na zgodność z normą PN-EN 443 pod kątem izloacji przed porażeniem prądem elektrycznym.

[4] Elgafy A., Merits of Employing Carbon Foam Fabrics in Firefighter's Helmet Shell, University of Cincinnati, 2012.

[5] Barnett D., Evaluation Of Fire-Fighting Helmet Surface Technology For High Radiant Heat Applications, University of Kentucky, 2003.

[6] Stroup D., McLane R., Twilley W., Full Ensemble and Bench Scale Testing of Fire Fighter Protective Clothing, National Institute of Standards and Technology, 2007.

[3] Taylor N., Challenges to Temperature Regulation When Working in Hot Environments, "Industrial Heatlh" Vol. 44, 2006, pp. 331-344.

mgr inż. Łukasz Dul - w latach 2013-2014 zajmował stanowisko asystenta w Instytucie Techniki Cieplnej PW. Obecnie jest doktorantem w tej samej jednostce na Wydziale Mechanicznym Energetyki i Lotnictwa PW. Autor artykułów naukowych o tematyce związanej z analizą polityki energetycznej kraju oraz oceną opłacalności farm wiatrowych. Przedmiotem pracy badawczej autora są przede wszystkim zagadnienia związane z obciążeniami cieplnymi oraz mechanicznymi odzieży ochronnej. 